\title{
Vascular Plant
}

National Cancer Institute

\section{Source}

National Cancer Institute. Vascular Plant. NCI Thesaurus. Code C14336.

The flowering herbs, shrubs, trees and ferns. These plants have vascular tissue,

consisting of xylem, which carries water and nutrients from the roots up the stem to the leaves, and the phloem, which carries sugar produced in the leaves to other parts of the plant. 